Acta Technologica Agriculturae 4

Nitra, Slovaca Universitas Agriculturae Nitriae, 2016, pp. 84-88

\title{
HIGH FREQUENCY INDUCTION TUBE FURNACE FOR DETERMINATION OF ASH MELTING TEMPERATURE
}

\author{
Tomasz DRÓŻDŻ , Paweł KIEŁBASA ${ }^{1 *}$, Maroš KORENKO², Piotr NAWARA', Krzysztof PIKUL ${ }^{1}$ \\ ${ }^{1}$ University of Agriculture in Krakow, Poland \\ ${ }^{2}$ Slovak University of Agriculture in Nitra, Slovak Republic
}

\begin{abstract}
The article describes the designed and manufactured tube furnace intended for, inter alia, determining the melting temperature of ash conforming to the standard of ISO-540:2001. The possibility of digital sample observation and several programs controlling the obtainable temperature enable to determine the test cycle in any case (convenient for the researcher). Reduction of testing time allows for the analysis of the observed phenomena, as well as more detailed research plan of samples, where substantial changes have been demonstrated.
\end{abstract}

Keywords: by-products of combustion ash melting; the quality of biofuels; high frequency induction heating; digital image analysis

Combustion of each of the solid fuel is associated with obtaining a certain amount of ash, constituting by-product of this process. The amount of ash is closely related to the type of fuel (Obernberger,1997), its chemical composition (Van Loo et al., 2002) and it represents distinctive feature of each fuel. Furthermore, the content of certain elements strictly determines the ash melting behaviour of the biomass. The presence of calcium and magnesium raises the melting temperature, whereas the presence of potassium decreases it (Obernberger, 1997; Van Loo et al., 2002). Presence of chlorides and low-melting aluminosilicates can also significantly decrease the melting point, what results in the creation of sinters and slag in the combustion chamber. Additionally, melted particles present in fly ash accumulate on the cooled walls of the furnace and heat exchangers. Because of this, the ash from straw, grasses and grains containing small amounts of calcium and large amounts of silicon and potassium is characterized by low melting temperature of ash in comparison to wood. Newly created ash during the combustion process can be divided into two parts: the volatile part (fly ash) carried by the gases; and a non-volatile part (bottom ash) collected and discharged from the lower part of the furnace combustion chamber. Furthermore, content of alkali metals, chlorine or sulphur in the combusted material can cause high temperature corrosion of heating surfaces of the boiler interior. For the materials used for energy purposes, there have been developed certain technical procedures that allow to determine the physical properties, such as the content of: moisture, ash, volatile components; determination of the combustion heat, calorific value, characteristic melting temperature of ash and chemical properties, such as content of sulphur (ash and combustible), carbon, hydrogen and nitrogen.
Currently, the lignocellulosic biomass is more and more commonly used in the power industry; it is normally supplied in granular form (pellets, briquettes). This biofuel is produced industrially from different raw materials, i.e. so-called energy plants (Kalembasa, 2006), species range of which is constantly expanding as a result of progressive research (Frączek et al., 2009; Frączek et al., 2011a; Frączek et al., 2011b; Mudryk et al., 2011; Mudryk et al., 2012; Mudryk et al., 2013). In large units (power plants, thermal power plants-CHP), it also occurs as an admixture to the hard coal and lignite, peat and other solid fuels. In the European Union and in the United States of America, the great importance is attributed to the development of methods for testing of fuels combusted in the boilers. Requirements imposed by standards and regulations (DIN 51730; ISO 1171:2010) for testing of physical and chemical properties of the material being burned resulted in creating normative research procedures and development of devices to determine these properties. One of the most important parameters relevant to the users of the furnaces is to determine the melting and flow temperatures of ash. Exceeding of these temperatures in the furnace causes flooding of grate with liquid ash (slag) and it disables the furnace from further work. These temperatures differ for cases in which the ash comes from pellet combustion and in which other fuel is combusted in admixture with pellets (Kalembasa, 2006). Therefore, the standards require that the manufacturer of material must indicate the information on melting and flow temperature of ash on the label of each single package. The currently used device for determining of the ash fusibility requires a long testing time due to the heating procedure specified by the standard PN-ISO 540:2001. Therefore, the development of a device that would relatively quickly (even with a reduction of the heating process specified by 
the standard PN-ISO 540:2001) ensure the determination of ash fusibility and with the possibility of immediate repeat of measurement is really crucial goal.

\section{Heating devices for testing of ash fusibility by tubular method}

In general, two types of high temperature heating elements are used in the devices for testing of ash fusibility with tubular method: silicate elements made of recrystallized silicon carbide for temperatures of up to approximately $1500{ }^{\circ} \mathrm{C}$; and elements made of molybdenum sulphide for temperatures up to $1850{ }^{\circ} \mathrm{C}$. These heating elements are characterized by high durability when exposed to high operating temperatures, increasing resistance (decreasing capacity) with increasing temperature, exceptional fragility and it is necessary to apply a special type of temperature control. Resistance wires and strips placed in ceramic materials are also applied as heating elements in some earlier models of the heating devices for testing fusibility of the ash. In addition to this, these devices must operate in a neutral gas environment in accordance with the standards PN-ISO 540:2001 and PN-82/G-04535.

\section{New solution for furnace for ash fusibility testing by tubular method}

Work performed and presented in articles (Gąsiorski et al., 2013a; Gąsiorski et al., 2013b) and acquired experience allowed us to propose a new approach to the ash fusibility furnace testing. Presented solution is adapted to flexible settings of the research program.

Characteristics of the device:

- it operates on the principle of using the phenomenon of electrical resonance and high-frequency induction heating;

- it quickly processes the heated ash samples in order to observe and determine the temperature of ash;

- it has a replaceable pipe made out of a conductive material (graphite), which, during the heating process, would emit carbon monoxide and carbon dioxide in respective proportions, providing a neutral atmosphere in its interior;

- it has multi-scroll inductor made of an electrically conductive water-cooled tubes in a closed circuit, cumulating energy of the electromagnetic field in a conductive graphite tube;

- it is relatively light, supplied with electric power AC $230 \mathrm{~V}$ and easy to carry.

\section{Construction and operation of the converter}

Laboratory device for testing of ash fusibility by tubular method is provided with a converter with a resonant load through which inductor transfers energy to the conductive graphite tube. The effect of energy transfer can be enhanced by increasing the value of current supplied through the inductor and increase in the operating frequency (Mućko, 2011).

In order to obtain high values of electric current and the minimal power dissipation at the same time, there is a transformer installed to the device, of which secondary side, on contrary to

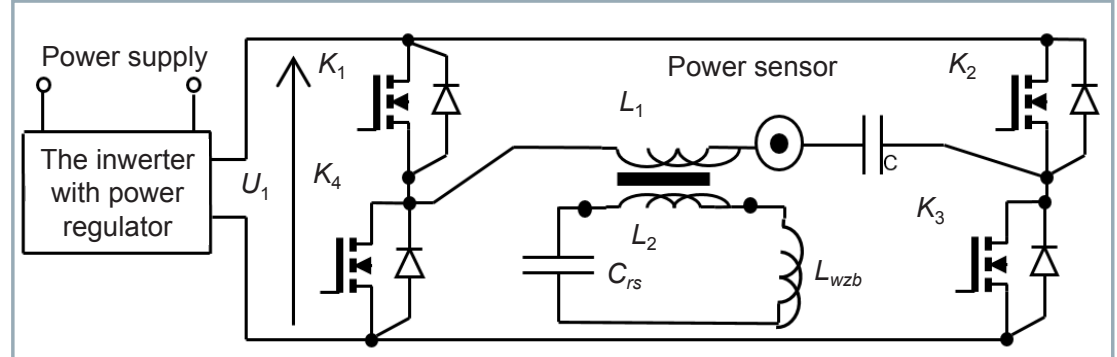

Figure 1 Simplified diagram of operation of the converter circuit

$U_{1}$ - supply voltage of the circuit; $K$ - MOSFET type power transistors; $D$ - turn diodes; $L_{1}$ - inductance of the primary side of the transformer; $L_{2}$-inductance of the secondary side of the transformer; $L_{s}$ - inductance of the other components of the resonance circuit (inductor with a graphite tube); $C_{r s}$ - the capacity of resonant capacitor and the capacity of the secondary side of the transformer; $R_{2}$ - a small resistance of the secondary side of the transformer (omitted here) the concentrated capacitance, circuit resistance and inductance of the inductor as well as resistance entered into to the circuit by heated graphite element, constitute a serial resonant circuit (Mućko, 2011). All values of the resonant circuit do not change during operation, that is the reason why the proposed system does not include PLL phase-locked loop, which would allow to automatically tune the trigger frequency pairs of power transistors in accordance to the resonant frequency of the entire system. Device powering is designed and manufactured in full $\mathrm{H}$-bridge circuit, in which the main branch is connected to the transformer and capacitor $C$, the locking component of the constant power supply (Figure 1).

The output rate used in the converter circuit with the resonant load is the constant voltage of $U_{s}$ value, which is transmitted to the load by means of keying. In the time range from 0 to $T_{1}$ (Figure 1 ), the keys $K_{1}$ and $K_{3}$ must be triggered and in the time range from $T_{1}$ to $T_{2}$, the keys $K_{2}$ and $K_{4}$ must be triggered. The process of activation and deactivation of respective pairs of keys is accompanied by the occurrence of voltage forcing function in the form of alternating voltage with the course similar to a sine wave on the resonant branches $R, L, C$. In the transformer primary side branch, there is a current sensor, enabling to detect the transition of current through zero point. Knowledge of the time when the current would cross the zero point is essential for control of respective pairs of the MOSFET type power transistors (control keys), providing the so-called "death-time" time interval for preventing both pairs of keys being triggered simultaneously.

There can occur certain problems with the operation of control circuits when operating under the frequencies above $150 \mathrm{kHz}$, because, at these values, field effects become significant (the effect of the approximation of the wires, the effect of current displacement or skin effect and others). It is not hard to reveal them when electronic circuits work at lower frequencies. Therefore, it is widely accepted that the control circuits work appropriately as long as the operation frequency would not exceed $150 \mathrm{kHz}$. The proposed solution, based on the 


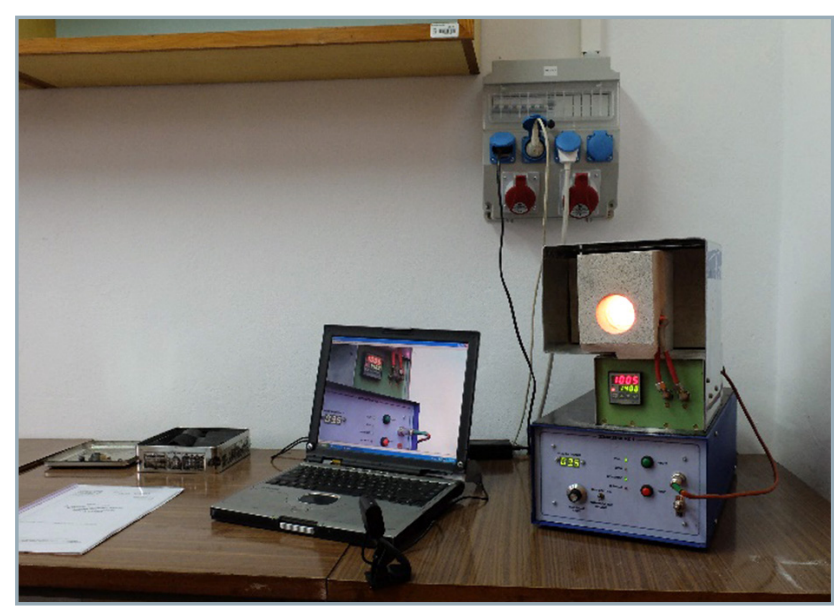

Figure 2

Image of the laboratory position

search for a compromise and the observation on laboratory prototype built under the existing circumstances, seems to be the solution close to the optimal one.

In practice, the working load of the device is on inductor made of copper pipe, connected serially with the capacitor battery. There is thermally isolated graphite tube constituting the operating chamber in the inductor.

Heating of the graphite tube takes place in the two-state process, turn on - turn off, controlled by a temperature controller with the "ramping" function.

Figures 2 and 3 show images of a prototype.

Technical parameters of the heating device (RZ-1) are as follows: network supply voltage $U=230 \mathrm{~V}$; active power $P=2.0 \mathrm{~kW}$; inductor operating frequency $f=$ $117 \mathrm{kHz}$; inductance $L_{w z b}=1.4 \mu \mathrm{H}$; capacity in the form of capacitor banks composed of a capacitor-type HC-03 (MitraKutno, 2014) with a total capacity of $C_{r s}=1.6 \mathrm{uF}$. Inverter dimensions: length $450 \mathrm{~mm}$; width $250 \mathrm{~mm}$; height $150 \mathrm{~mm}$. The dimensions of the output system of the inductor: length $250 \mathrm{~mm}$; width $150 \mathrm{~mm}$; height $100 \mathrm{~mm}$; the dimensions of inductor: external diameter $70 \mathrm{~mm}$; length $45 \mathrm{~mm}$. The inductor was made of copper pipes with a diameter of $6 \mathrm{~mm}$ with 6 rolls. The inductor is effectively cooled with water in a closed circuit. The device can operate up to a temperature of $1500^{\circ} \mathrm{C}$ (maximally up to $1600^{\circ} \mathrm{C}$ ).

To set the temperature, $\mathrm{RE}-3$ temperature controller with the "ramping" function LUMEL SA by Zielona Gora company, working in the system of PID with the S PtRh-Pt (platinum-rhodium/platinum) type sensor for temperatures up to $1600{ }^{\circ} \mathrm{C}$ was used. The temperature sensor was placed in the middle of the graphite tube. The image was recorded during the tests using the Logitech HD 720p camera and using welding filter glass $50 \mathrm{~mm}$ of the DIN6 blackout.

\section{Pellet combustion process and the ash creation}

Pellets should be burned only in furnaces suitable for combustion. Wooden pellets contain approximately $80 \%$ of volatile substance (in percentage of dry weight), which means that during the combustion $80 \%$ of weight is converted into gases, and the remaining part is turned into charcoal. In the pellet combustion, there are three stages: drying (evaporation of water), the gasification (pyrolysis) and the combustion and post-combustion of charcoal. During this process, $4 / 5$ of energy is released in

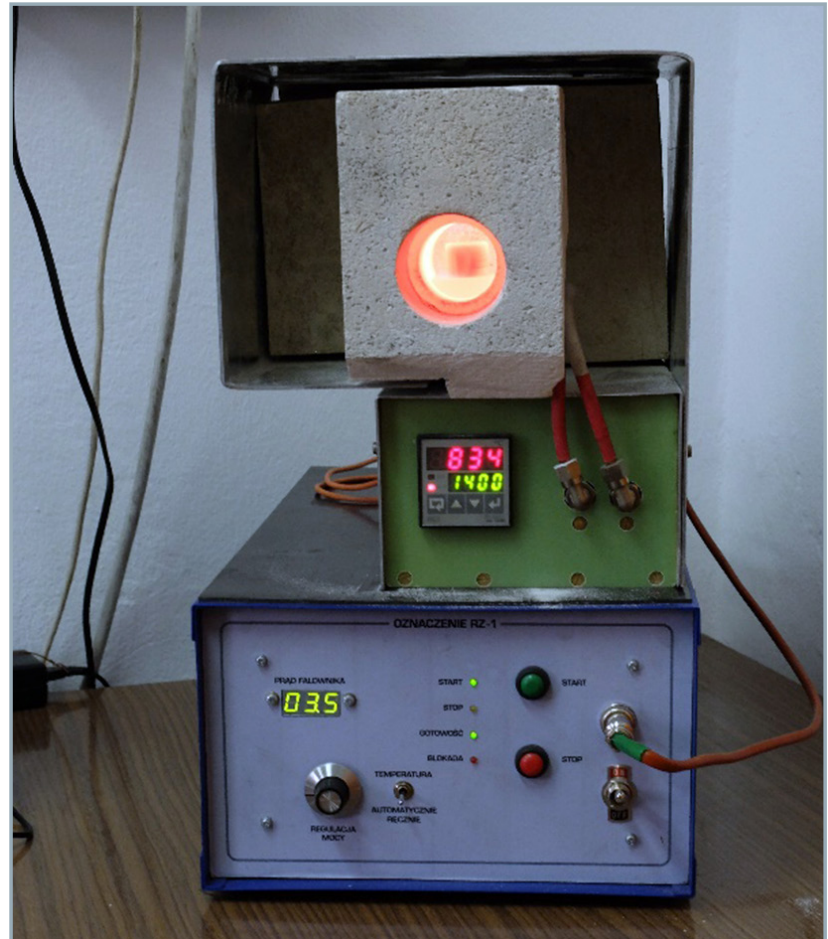

Figure 3 Image of inductor with a temperature controller and its registration

a gas form, and the remaining $1 / 5$ is contained in the form of charcoal.

After putting the pellets to the furnace combustion chamber, water contained in the pellets is evaporated due to the heat accompanying the process. If the water content in the flare pellet is low, the process is very fast, if it is high, then the process is proceeding slowly with a large loss of thermal energy for drying the wet pellets. The gasification process, namely gas evolution, takes place during the further pellet heating. The temperature necessary for the achieving of this process is about from $260{ }^{\circ} \mathrm{C}$ to $280{ }^{\circ} \mathrm{C}$. Then arise: gases such as carbon monoxide (CO), hydrogen $\left(\mathrm{H}_{2}\right)$ and methane $\left(\mathrm{CH}_{4}\right)$ and other hydrocarbons and charcoal remains. If there is a sufficient amount of air in the furnace, the gases would burn, the temperature would rise and the created charcoal begins to burn out. Ash comprising of predominantly noncombustible mineral compounds remains after charcoal combustion. The ash represents an undesirable product, because it is necessary to treat the flue-gases and to dispose of ash and slag. The ash content is closely related to dirt, sand salts absorbed by bar and wood during the process of tree growth.

Wooden pellets are characterized by a low ash content, typically within the range from $0.5 \%$ to $15 \%$. The main components of biomass are carbon $(\mathrm{C})$, hydrogen $(\mathrm{H})$, oxygen $(\mathrm{O})$, nitrogen $(\mathrm{N})$, sulphur $(\mathrm{S})$ and chlorine $(\mathrm{Cl})$. The whole composition of the biomass is characterized by a great diversity resulting from the fact that it depends on, e.g. the place where the plants have grown, methods of their cultivation and fertilization. The main components are: $\mathrm{Al}, \mathrm{Ca}, \mathrm{Fe}, \mathrm{K}, \mathrm{Mg}, \mathrm{Na}, \mathrm{P}, \mathrm{Si}, \mathrm{Ti}$, and the additional components are: $\mathrm{As}, \mathrm{Ba}, \mathrm{Cd}, \mathrm{Co}, \mathrm{Cr}, \mathrm{Cu}, \mathrm{Hg}, \mathrm{Mn}, \mathrm{Mo}, \mathrm{Ni}, \mathrm{Pb}, \mathrm{Sb}, \mathrm{Tl}, \mathrm{V}, \mathrm{Zn}$. Ash components such as calcium and magnesium usually contribute to increase of ash melting point, whereas 
potassium significantly reduces the melting temperature of ash. The ash melting point can also decrease significantly, if the substances such as chlorides and alkali and low melting aluminosilicates are present in the biomass (Chungen et al., 2008). Due to the ash content at around $10 \%$, as well as because of the alkali components in boiler installations, special equipment must be used to remove the ash. Arsenic, cadmium, chromium, lead and mercury are trace metals present in small quantities in ash from biomass. The chemical composition of biomass is of a high heterogeneity, and components, such as oxygen, chlorine, and nitrogen results in the emission of dioxins, furans and hydrogen chloride. In the biomasses with a high nitrogen content, there is high concentration of protein and the nitrogen is present in the form of amino groups $\left(-\mathrm{NH}_{2}\right)$ in such cases. When the biomass density is low, it is necessary to provide a large surface area for the storage and it is difficult to transport it effectively and to distribute it to the furnace. Volatile substances, that hinder the control over the combustion process, represent a large part of biomass. The temperature referred to as the flowing temperature of ashes varies for different types of pellets, and it is typically from between $760{ }^{\circ} \mathrm{C}$ to $1500{ }^{\circ} \mathrm{C}$ (rose without spikes) (Kowalczyk-Juśko, 2007; Rybak, 2006). Exceeding of the flow temperature of ash during the flue gas combustion can cause sedimentation of these gases on the walls of the tubes, creating the thick, difficult to remove, layers. It should also be noted that despite the low content of potassium salt and sodium salt in the flare pellet, they can form a sticky ash covering the outer surfaces of the boiler and grate.

\section{Preparation of ash sample for testing}

A test sample constitutes the ash obtained from the incineration of research material or ash obtained, e.g. from combustion installations for solid fuels. The ash samples for determination of the ash fusibility can be observed only under the condition that the combustion of fuel, from which the ash comes from, was completed (the sample cannot comprise of unburned fuel particles). Collected sample is placed in a special mortar and it is then pounded with a pestle, preventing any contamination of the sample. After trituration, ash is sieved through a control sieve with an aperture size of $0.075 \mathrm{~mm}$; the remaining material on the sieve is triturated again. Thus prepared ash is moistened with distilled water, stirred and then kneaded in a mould made of brass or stainless steel in the shape of: pyramid with the base of an equilateral triangle (height of a sample should not be higher than $19 \mathrm{~mm}$, and from two to three times larger than the length of the side base); a cube (with the side length within the range from $3 \mathrm{~mm}$ to $7 \mathrm{~mm}$ ); roll (with the height within the range from $3 \mathrm{~mm}$ to $9 \mathrm{~mm}$ and a diameter of equal to height); or a truncated cone (with the height of $4 \mathrm{~mm}$ and a diameter of $3 \mathrm{~mm}$ at the base and $1.5 \mathrm{~mm}$ in the truncated part). The edges of the obtained samples should be absolutely sharp in order to facilitate sample observation during melting. The resulting sample should be dried and then placed on a plate made of a material not liable to deformation, non-reactive and not absorbing the ash during the observation. It is recommended to make the plates of sintered alumina or mullite. The next step is to remove the organic substances from the sample by slow heating in air to a temperature of approximately $815^{\circ} \mathrm{C}$. This stage can be carried out in a furnace for determination of the ash fusibility. The ash sample prepared in such way is used for further research.

\section{Determination of characteristic temperatures of ash fusibility}

To determine the melting temperature of ash and the corresponding behaviour (image) of the ash sample heated in a tube, a digital camera and temperature controller RE3 (thermocouple signal) were used.

Temperature measurement was performed using a thermocouple (PtRh-Fri) with additionally attached compensation cables. The voltage obtained from the thermocouple represents the reference voltage for the temperature controller, and a built-in "ramping" allows to set a fixed speed rise of the temperature in the space with the heated sample within certain temperature ranges.

During the test, the compacted ash sample is placed on a specially shaped graphite base which is inside the levelled and unilaterally graphite tube closed with insulating material.

A tubular method for determining the ash fusibility at high temperature is determined by the standard PN-ISO 540:2001. It involves the heating of a suitably shaped compacted ash sample (with sharp edges), at a rate of $30^{\circ} \mathrm{C} \mathrm{min}^{-1}$ to a temperature of $900^{\circ} \mathrm{C}$ and at a rate $10^{\circ} \mathrm{C} \mathrm{min}^{-1}$ to temperatures above $900^{\circ} \mathrm{C}$ in a suitable neutral gaseous environment produced by heated graphite tube. Direct observation of the behaviour of the sample or the recording of its image allows to determinate the characteristic melting temperature of ash on the basis of a visual assessment of changes of the testing moulder contours, observed in the measuring grid. Figure 4.

An image of the whole process of heating the sample in the tube, since the moment when the initial temperature reaches standard value of $750{ }^{\circ} \mathrm{C}$, is recorded (20 images per minute) for subsequent determination of parameters of ash fusibility. Then, the image is subjected to the numerical study (Małkiński et al., 2013).

To determine the shape characteristics, methods and techniques of image analysis were used. Image analysis
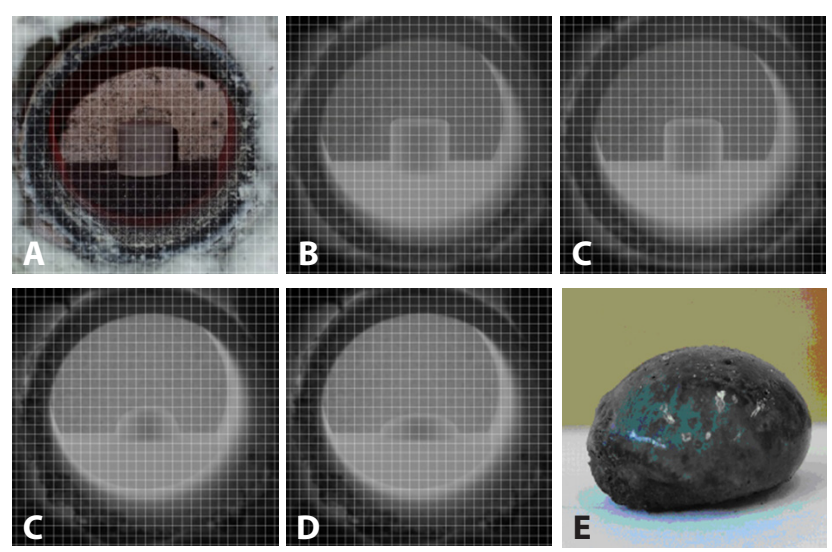

Figure 4

The ash sample

A - before the measurements; $\mathrm{B}-t_{s}$ ash sintering temperature; $\mathrm{C}-t_{a}$ ash iridescence-temperature; $\mathrm{D}-t_{d}$ ash melting temperature; $\mathrm{E}-t_{c}$ ash flow temperature; $\mathrm{F}$ - view of the sample after testing 
is the process of information processing (the input data is an image form and output data is stored in the form of e.g. numbers, an array of numbers). In order to accomplish these tasks, the computer systems are used. Aphelion is an advanced application that is used for processing of the images and quantitative analysis is used in rapid prototyping applications, the development of new imaging techniques, training of the computer "look" and application deployment. Aphelion, the most commonly used application in the majority of software products used for image analysis, enables to apply various features to images (e.g. patterns according to PN) and make comparisons, move, smooth, mix and match items from different collections. Despite the fact that the features overlaps with each other, they are disjoint. The images analysed in Aphelion can be binary, grey, or colourful, as well as of any size. As a result of using the filter, we can perform algebraic operations using numbers depicted by the colour or grey level in the vicinity of the analysed point and provide the characteristic shape when determining ash fusibility. The next stage of image analysis is analysis of image with the recorded temperature value data, where the characteristic shape is represented. The laboratory position built with Aphelion platform will enable to automatically analyse the characteristic contours and ash fusibility temperatures by tubular method.

\section{Conclusions}

Constructed prototype laboratory meets the requirements of standards DIN 51730 and PN-82/G-04535. The assessment study of various ashes showed that the proposed solution can be applied to:

- determination of ash fusibility by tubular method for bottom ash obtained from the combustion of lignocellulose biomass, and mixtures of biomass with coal, lignite, peat, as well as these minerals without biomass. This does not preclude the possibility of a much broader research on solid fuels not listed;

- faster approximate determination of ash fusibility temperature heated sample of compacted ash, deviating from accepted standards;

- almost immediate re-audit of the another ash sample, in a new graphite tube placed in the inductor, after removing the pipe previously used;

- preliminary tests of the composition and contamination of biomass are carried out in accordance with determined ash flow temperature;

- the position can also be used to determine the ignition temperature of the pellets. Ignition temperature represents an important parameter of each fuel, characterizing its properties, and each fuel quality specification requires the determination of this parameter;

- image analysis allowing to quickly implement Aphelion platform in order to describe characteristic shape temperatures of ash fusibility.

\section{References}

CHUNGEN, Y. - ROSENDAHL, L. A. - SŘREN, K. 2008. Grate-firing of biomass for heat and power production. Aalborg East, Denmark: Institute of Energy Technology, Aalborg University, DK-9220. In
Progress in Energy and Combustion Science, vol. 34, 2008, pp. 725-754.

FRĄCZEK, J. - MUDRYK, K., WRÓBEL, M. 2009. Klon jesionolistny Acer negundo L. - Nowy potencjalny gatunek energetyczny. In Acta Agrophysica, vol. 14, 2009, no. 2, pp. 313-322.

FRĄCZEK, J. - MUDRYK, K. - WRÓBEL, M. 2011a. Rożnik przerośnięty Silphium perfoliatum L. - źródło biomasy do produkcji biopaliw stałych. In Inżynieria Rolnicza, vol. 6, 2011, no. 131.

FRĄCZEK, J. - MUDRYK, K. - WRÓBEL, M. 2011b. Wybrane właściwości fizyko-mechaniczne topinamburu Helianthus tuberosus L. In Inżynieria Rolnicza, vol. 6, 2011, no. 131.

GĄSIORSKI, A. - POSYŁEK Z. 2013a. Nietypowe rozwiązanie indukcyjnego wysokoczęstotliwościowego pieca tyglowego. In Przegląd Elektrotechniczny, vol. 89, 2013, no. 12, pp. 230-233.

GĄSIORSKI, A. - POSYŁEK, Z. 2013b. Praktyczna realizacja rezonansowego falownika szeregowego pracującego z potrojona częstotliwością względem częstotliwości przełączania elementów. In Przegląd Elektrotechniczny, vol. 89, 2013, no. 12, pp. 370-373.

KALEMBASA D. 2006. Ilość i skład chemiczny popiołu z biomasy roślin energetycznych. In Acta Agrophysica, 2006, no. 7(4), pp. 909-914.

KOWALCZYK-JUŚKO A. 2007. Źródła biomasy na cele energetyczne. In Bioenergetyka podkarpacka. Jarosław : PWSZ, 2007.

MAŁKINSSKI, W. - ZAJĄC, J. 2013. Wybrane problemy wizyjnej analizy właściwości termicznych materiałów przy wykorzystaniu analizatora do wyznaczania punktów charakterystycznych przemian fazowych. In Elektronika, vol. 54, 2013, no. 4, pp. 51-55. MITRA-KUTNO. 2014. Filtry i Kondensatory. In Katalog Mitra Sp. zo. o.

MUĆKO, J. 2011. Tranzystorowe falowniki napięcia z szeregowymi obwodami rezonansowymi. Bydgoszcz : Wydawnictwa Uczelniane Uniwersytetu T Technologiczno-Przyrodniczy im. Jana i Jędrzeja Śniadeckich w Bydgoszczy.

MUDRYK, K. - FRACZEK, J. - SLIPEK, Z. - FRANCIK, S. - WROBEL M. 2013. Chosen physico-mechanical properties of cutleaf coneflower (Rudbeckia laciniata L.) shoots. In Engineering for Rural Development Jelgava. Retrieved from: http: //tf.llu.Iv/conference/ proceedings2013/Papers/122_Mudryk_K.pdf

MUDRYK, K. - WRÓBEL, M. 2011 a. Briquetting and quality of Virginia mallow biomass briguettes. In PIEKARSKI, W (Eds). Rozdział IV w: The acquisition and processing of biomass of Virginia mallow for energy purposes. Warszawa : Wydawnictwo “Wieś jutra”, 2011.

MUDRYK, K. - WRÓBEL, M. 2012. Słonecznik wierzbolistny Helianthus salicifolius A. Dietr. - na cele energetyczne. In Inżynieria Rolnicza, 2012, no. 2 (136), pp. 249- 256.

OBERNBERGER, I. 1997. Nutzung fester Biomasie in Verbrennungsanlagen unter besonderer Berücksichtibunb des Verhaltens aschebildender Elemente. In Schriftenreihe"Thermische Biomassenutzung", Band 1, Graz, Österreich : dbv-Verlag der Technischen Universität Graz, 1997.

RYBAK, W. 2006. Spalanie i współspalanie biopaliw stałych. In Oficyna wydawnicza Politechniki Wrocławskiej, 2006.

VAN LOO, S. - KOPPEJAN, J. (Eds.) 2002. Handbook of Biomass Combustion and Co-firing. In IEA Bioenergy Task 32.

\section{Norms}

DIN 51730 Testing of solid fuels - Determination of fusibility of fuel ash (Badanie paliw stałych - Określanie topliwości popiołów).

ISO 1171:2010 Solid mineral fuels - Determination of ash (Stałe paliwa mineralne - Określenie popiołu).

PN-ISO 540:2001 Paliwa stałe, Oznaczanie topliwości popiołu w wysokiej temperaturze metodą rurową.

PN-82/G-04535 Paliwa stałe. Oznaczanie charakterystycznych temperatur topliwości popiołu. 